\title{
船社の寄港挙動モデルによる国際コンテナ航路体系の分析
}

\section{〜 東アジアー北米西岸航路について}

A modeling of Carriers' Behavior of Container Ship Calling at Ports

- Routes between East Asia and West Coast of North America-

\section{渡部 富 博* 善見政和 ${ }^{* *}$ 石橋宏典***}

Tomihiro WATANABE Masakazu YOSHIMI Hironori ISHIBASHI

\section{1.はじめに}

近年，香港やシンガポールをはじめとしたアジアの 主要港湾での国際コンテナ貨物の取扱量の増大, コン テナ船の大型化，コンソーシアム（企業連合）の再編 等，我が国の国際海上コンテナ輸送をとりまく環境は 大きく変化している．特に，船社がより一層のサービ ス向上やコスト削減のために, 大型コンテナ船を主要 港湾にのみ寄港させ，貨物取り扱いの集約化と運航の 迅速化・安定化を図る動きが盛んであり，今後の我が 国の国際コンテナターミナルの整備を考えるにあたつ ては，日本のみならず東アジア諸国の今後の経済発展 の動向やコンテナターミナルの状況分析，コンテナ船 の大型化の動向分析等に加え, コンテナ輸送ルート形 成に関わる船社行動分析が不可欠となっている.

船社の寄港挙動の分析としては，木村"が同盟船社と 非同盟船社の競争を考慮し, 船社の運航採算性を考虑 した寄港地選択モデルを開発している．また，郭等" は，国家レベルでのいくつかの経済主体が，ゲーム理 論に基づいた合理的な行動をとるとして評価モデルを 構築し，東アジア-北米航路の国際コンテナネットワー ク形成について分析している．黒田等"1はコンテナ船の 寄港挙動を港湾整備主体, 船社, 荷主をゲームの参加 者とするゲームの理論のなかで捉え, シュタッケルベ ルグ均衡解を求めることにより，船社の行動を分析し ている．家田等" は，港湾内および港湾間の貨物流動を ネットワーク配分問題としてモデル化し，船社グルー プのコスト最小化や貨物全体の流動コストの最小化等 の配分原理の違いが現象再現に及ぼす影響等を分析し ている.

これら研究は, 船社の挙動を運送費用等の最適化等 に基づくものとして捉えることが基本となっているが， 港湾整備とコンテナ貨物輸送体系の関連分析など，今 後の我が国の港湾整備を考えるうえで不可欠な事項を 必ずしも十分に取り込んだモデルとはなっていない。

キーワード：物資流動，経路選択，港湾計画

* 正会員 : 工修 運輸省港湾技術研究所 主任研究官

（广239-0826 横須賀市長瀬3-1-1 TEL/FAX 0468-44-5035）

** 正会員 : 工修 運輸省港湾技術研究所 計画基準研究室長

（テ239-0826 横須賀市長瀬3-1-1 TEL/FAX 0468-44-5035）

***：工修 福岡市港湾局計画課

（ ₹812-3213 福岡市博多区石城町13-13 TEL092-282-7130 FAX 092-291-3185)
このような状況のもと，筆者等 ${ }^{51}$ は，船社の寄港行動 を説明するモデルの検討を行い，各国の貨物がダイレク 卜貨物として，あるいはフィーダー貨物として輸送され る状況を説明するモデルを構築している．しかしながら， 構築モデルは，ルートの選択確率を求めるモデルの説明 変数の説明力が弱い，今後の港湾整備のあり方を考える 上で不可欠な各種の政策変数の導入が十分ではない等の 課題を抱えていた。

以上の背景を踏まえ，本分析は，今後の我が国のコン テナターミナル整備を考える際に必要となる船社の将来 の寄港行動の検討に資するために，荷動き量が大きく船 社間の競争も激しい東アジア-北米西岸航路（東航）を 対象に，日本を中心とした東アジア地域でのコンテナ貨 物の流動状況を国・地域間といったマクロな視点で捉え， 特にコンテナターミナル整備と船社の行動に着目し，そ の寄港地選択を説明するモデルの再構築を行い，国際コ ンテナ航路体系の分析を行ったものである.

\section{2. 東アジアー北米西岸航路（東航）の概要}

\section{(1)運航ルートの特徽}

表-1に，1997年末時点の東アジア-北米西岸航路(全 37ルート)の就航隻数と寄港港湾数, 寄港国・地域を示 す。

世界一周航路や地中海，北米東岸，カリブ海航路等と 接続している航路については, 就航コンテナ隻数が10隻 を越えるルートがあるものの，東アジア-北米西岸航路 のみのルートに関しては，5あるいは6隻のコンテナ船の 投入がほとんどである.

また，寄港港湾数については，アジア全体で4〜 6寄港 が多い.日本への寄港は, 東京湾29ルート, 伊勢湾16ル 一ト，大阪湾27ルートとなっており，東京湾と大阪湾に は7〜8割の航路の船舶が寄港していることがわかる. ま たこの三大湾のいずれにも寄港するルートが14ルート， 博多港, 清水港, 仙台港等の地方の港湾にも寄港するル 一トが8ルートとなっている. そのほか, 東アジアの主 要国への寄港をみると，香港への寄港が26ルート，台湾 への寄港が 23ルートと, 多くのルートがこれらの国に 寄港していることが伺える，中国については，近年寄港 ルートが増加しており，9ルートが寄港している．なお， シンガポールについては, 北米西岸航路に関しては, 
表-1＼cjkstart東P邨一北米西岸航路の就航隻数と寄港地(97年)

\begin{tabular}{|c|c|c|c|c|c|c|c|c|c|c|c|}
\hline \multirow{3}{*}{ 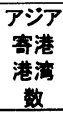 } & \multirow{3}{*}{ 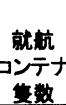 } & \multicolumn{10}{|c|}{ アジア地城での寒港港核(注 1) } \\
\hline & & \multirow[b]{2}{*}{$\begin{array}{c}\text { 東京 } \\
\text { 湑 }\end{array}$} & 日 & \multicolumn{2}{|c|}{ 本 } & \multirow{2}{*}{ 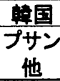 } & \multirow{2}{*}{$\begin{array}{l}\text { 台流 } \\
\text { 高雄 } \\
\text { 基隆 }\end{array}$} & \multirow[t]{2}{*}{ 香港 } & \multirow[t]{2}{*}{ 中国 } & \multirow{2}{*}{$\begin{array}{l}\text { シンカ } \\
\text { ポール }\end{array}$} & \multirow{2}{*}{$\begin{array}{l}\text { Pジ } \\
\text { の他 } \\
\text { の国 }\end{array}$} \\
\hline & & & $\begin{array}{l}\text { 伊學 } \\
\text { 济 }\end{array}$ & $\begin{array}{l}\text { 太阪 } \\
\text { 湾 }\end{array}$ & $\begin{array}{l}\text { その } \\
\text { 地 }\end{array}$ & & & & & & \\
\hline 11 & 12 & 0 & 0 & 0 & (2) & 0 & () & 0 & & 0 & 0 \\
\hline 7 & 15 & 0 & & 0 & (0) & & 0 & 0 & & 0 & \\
\hline 7 & 14 & 0 & & 0 & 0 & & 0 & 0 & 0 & 0 & \\
\hline 7 & 9 & 0 & 0 & 0 & & 0 & 0 & 0 & & 은 & \\
\hline 6 & 7 & 0 & 0 & 0 & (c) & 0 & & & & & \\
\hline 6 & 6 & 0 & 0 & 0 & & & 0 & 0 & & & 0 \\
\hline 6 & 6 & 0 & 0 & & 0 & 0 & & 0 & 0 & & \\
\hline 6 & 6 & 0 & & 0 & & & & 0 & 0 & 0 & 0 \\
\hline 6 & 6 & 0 & & 0 & & 0 & (2) & 0 & & & \\
\hline 6 & 5 & 0 & 0 & 0 & (2) & & & & 0 & & \\
\hline 5 & 16 & 0 & & 0 & & 0 & 0 & 0 & & & \\
\hline 5 & 13 & 0 & 0 & 0 & & & 0 & 0 & & & \\
\hline 5 & 13 & 0 & & 0 & & 0 & & 0 & & 0 & \\
\hline 5 & 11 & 0 & 0 & 0 & & & 0 & 0 & & & \\
\hline 5 & 6 & 0 & 0 & 0 & & & 0 & & & & 0 \\
\hline 5 & 6 & 0 & 0 & 0 & & & 0 & & 0 & & \\
\hline 5 & 6 & 0 & & 0 & & & & & 0 & & \\
\hline 5 & 5 & 0 & 0 & 0 & 0 & & & 0 & & & \\
\hline 5 & 5 & 0 & 0 & 0 & & & & & (2) & & \\
\hline 5 & 5 & 0 & 0 & 0 & & & 0 & 0 & & & \\
\hline 5 & 5 & 0 & 0 & 0 & & & 0 & 0 & & & \\
\hline 5 & 5 & 0 & & 0 & & 0 & 0 & 0 & & & \\
\hline 4 & 11 & & & & & 0 & 0 & 0 & & 0 & \\
\hline 4 & 7 & & & & & & 0 & 0 & & 0 & 0 \\
\hline 4 & 6 & 0 & & 0 & & & 0 & 0 & & & \\
\hline 4 & 6 & & & & & & & 0 & 0 & 0 & 0 \\
\hline 4 & 6 & & & & & & (2) & 0 & & 0 & \\
\hline 4 & 5 & 0 & 0 & & 0 & 0 & & & & & \\
\hline 4 & 5 & 0 & 0 & 0 & & & & 0 & & & \\
\hline 4 & 5 & 0 & & 0 & & & 0 & 0 & & & \\
\hline 4 & 5 & 0 & & 0 & & 0 & & 0 & & & \\
\hline 4 & 5 & 0 & & 0 & & 0 & & & 0 & & \\
\hline 3 & 8 & 0 & & 0 & & 0 & & & & & \\
\hline 3 & 5 & & & & & 0 & 0 & 0 & & & \\
\hline 3 & 5 & & & & & 0 & 0 & 0 & & & \\
\hline 2 & 5 & & & & & & 0 & & & 0 & \\
\hline 1 & 5 & & & & & & 0 & & & & \\
\hline$\pi-12$ & & 29 & 16 & 27 & 8 & 15 & 23 & 26 & 9 & 11 & 6 \\
\hline
\end{tabular}

注1)寄港港流の○は1奇港港湾, ○は2奇港港湾, ○は3寄港港湾

注2) 東京湾=東京·横浜港，伊勢湾=名古屋港，大阪湾=大阪·神戸港

(参考文献6)より作成)

11ルートにとどまっている．

このように，東アジア-北米西岸航路においては，ア ジアの主要港湾である日本の三大湾, プサン, 高雄, 香港, シンガポールの7地域/港浮のすべてに奇港する といったルートはわずかに2ルートだけであり，各ルー 卜とも寄港地数と寄港地を選択したうえで, 周回日数 と投入隻数に見合ったルート形成がなされていること がわかる.

\section{（2）投入コンテナ船・寄港港湾数}

1997年と1994年における東アジア一北米西岸航路に 投入されたコンテナ船と，アジア地域における寄港港 湾数（ルート平均）を表-2に示す. 表-2より，1994年 と1997年では，コンテナ船の大型化が進んでおり，日 本をはじめとした各ルートの寄港地数も減少している ことが伺える.船型分布詳細は (4)に示す.

表-2 東アジアー北米西岸航路のコンデ船と寄港数

\begin{tabular}{|c|c|c|c|c|c|}
\hline & \multirow{2}{*}{$\begin{array}{l}\|-卜 \\
\text { 数 }\end{array}$} & \multicolumn{2}{|c|}{ ユンンテす船 } & \multicolumn{2}{|c|}{ 스平均寄港港湾数 } \\
\hline & & 投入隻数 & 平均船型 & 日本 & アジアア計 \\
\hline 1997 & 37 & 271隻 & 2929TEU & 2.3港 & 4.9港 \\
\hline 1994 & 37 & 254隻 & 2675TEU & 2.6港 & 5.1港 \\
\hline
\end{tabular}

(各年度参考文献6)より作成)

\section{（3 )コンテナ貨物流動}

国際コンテナ貨物輸送においては，港湾毎の取扱量 は比較的容易に入手することができるが, フィーダー 輸送を含めた各ルート毎のコンテナ輸送量は, 船社等 の情報を用いて集計することが必要なため，詳細デー 夕を入手できないことが多い，このような状況のなか， 対米国とのコンテナの動きについては，米国税関のデ 一夕に基づく資料が利用可能となっている.

その資料に基づく1997年1月〜3月の 3 ヶ月間におけ る東アジアー北米西岸航路（東航）のコンテナ貨物の 流動状況を表-3に示す．この期間にアジア諸国から北 米西岸には77.9万TEUの貨物が輸送されており，うち5 9\%にあたる46.1万TEUの貨物が自国の港湾から北米西 岸向けの本船に積み込まれ, 残りの31.8万TEUが他の国 ・地域の港湾にフィーダー輸送（以下「フィーダー貨 物」と呼ぶ）されている.フィーダー輸送先としては， 香港が最も多く17.2万TEU, 次いで台湾が5.5万TEU, シ ンガポール4.7万TEU等となっている.

各国の港湾の本船積コンテナ貨物は, 自国の背後圏 からの貨物（以下「ダイレクト貨物」と呼ぶ）と，他 港からフィーダー輸送され当該港湾で本船に積み替え られる貨物（以下「トランシップ貨物」と呼ぶ）から

表-3＼cjkstart東アジアー北米西岸航路（東航）におけるコンテナ貨物流動（1997年1月～3月）

(TEU)

\begin{tabular}{|c|c|c|c|c|c|c|c|c|c|c|c|c|}
\hline \multirow{2}{*}{ 輸出国 } & 北米西岸 & 出出国の & $71-4-$ & \multicolumn{9}{|c|}{ 本船積みを行う国・地域 } \\
\hline & 輸出貨物 & 本船積 & 貨物 & 東京湾 & 太阪湾 & 伊勢湾 & 北部九州 & 韓国 & 台湾 & 香港 & シンカ゚ポール & その他 \\
\hline 日本 & 149,728 & 147,217 & 2,511 & 0 & 0 & 0 & 0 & 1,643 & 142 & 172 & 74 & 479 \\
\hline NIES4 小計 & 271.815 & 259,375 & 12,440 & 3,404 & 1.257 & 10 & 0 & 86 & 6.400 & 840 & 292 & 152 \\
\hline 韓国 & 49,500 & 48,115 & 1,385 & 641 & 509 & 10 & 0 & 0 & 94 & 67 & 56 & 8 \\
\hline 台湾 & 106,829 & 105,680 & 1,149 & 309 & 143 & 0 & 0 & 28 & 0 & 421 & 163 & 85 \\
\hline 香港 & 103,041 & 96,682 & 6,359 & 1,281 & 564 & 0 & 0 & 4 & 4,382 & 0 & 73 & 55 \\
\hline シンガポール & 12,445 & 8,897 & 3,548 & 1,173 & 41 & 0 & 0 & 54 & 1,923 & 352 & 0 & 4 \\
\hline ASEAN4 小圾 & 118,247 & 10,285 & 107,962 & 7,303 & 1,521 & 0 & 0 & 1.580 & 42,356 & 8.866 & 46,191 & 145 \\
\hline 夕1 & 38,741 & 2,913 & 35,828 & 3,186 & 1,110 & 0 & 0 & 786 & 17,053 & 4,685 & 8,996 & 13 \\
\hline マレーシア & 27,662 & 5,588 & 22,074 & 1,445 & 164 & 0 & 0 & 4 & 3,819 & 1,156 & 15,479 & 6 \\
\hline インドネシア & 29,820 & 142 & 29,678 & 1,459 & 176 & 0 & 0 & 48 & 5,380 & 1,213 & 21,394 & 8 \\
\hline フィリピン & 22,024 & 1,642 & 20,382 & 1,214 & 71 & 0 & 0 & 742 & 16,103 & 1,811 & 322 & 119 \\
\hline 中国 & 239,608 & 44,223 & 195,385 & 11,039 & 6,501 & 75 & 0 & 9,248 & 6,484 & 161,801 & 228 & 9 \\
\hline Total & 779,397 & 461,099 & 318,298 & 21,746 & 9,279 & 85 & 0 & 12,557 & 55,381 & 171,679 & 46,785 & 785 \\
\hline
\end{tabular}


なる．表-3より，各港湾での本船積コンテナ貨物のう ち, シンガポールでは 8 割強, 香港では 6 割強, 韓国 では 2 割，そして日本では 2 割弱が，他港からフィー ダー輸送され当該港湾で本船に積替えられるトランシ ップ貨物であることがわかる.

\section{(4)投入船型}

図-1に，東アジア-北米西岸航路に就航しているコン テナ船の船型構成を示す. 1994年と1997年を比較する と, 1,000〜1, 999TEUクラス, 2,000〜2,999TEU積みの コンテナ船の比率が減少し $3,000 \sim 3,999 T E U や 4,000$ 4, 999TEU, 更には5,000TEU積みを超える大型コンテナ 船の構成比率が大きくなっていることが伺える.

コンテナ船の大型化は急激に進みつつあり，欧州航 路では最近になって6,000TEU積みの船舶の運航も開始 されている. 現在建造中の船舶も6,000TEU積みを超え

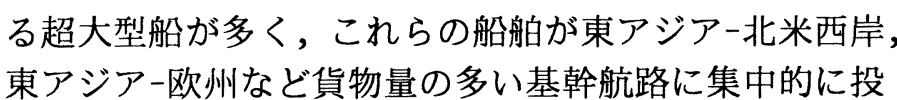
入されるものと予想される. また, コンソーシアムに より, 船社間の効率的な配船が可能となり, 集貨体制 との関連のなかで自由度が増加し, 船舶の大型化をよ り進めることになると考えられる．船型の大型化は， 一隻あたりの港湾でのコンテナ貨物取扱量を増加させ ることから, 荷役能力を現状程度とすれば, 荷役に要 する時間増加となり, また，船舶の運航費用も高くな るため, 周回日数・船舶の運航スピードを現状とする 制約条件下では, 寄港港数の減少をもたらすことも考 えられる。

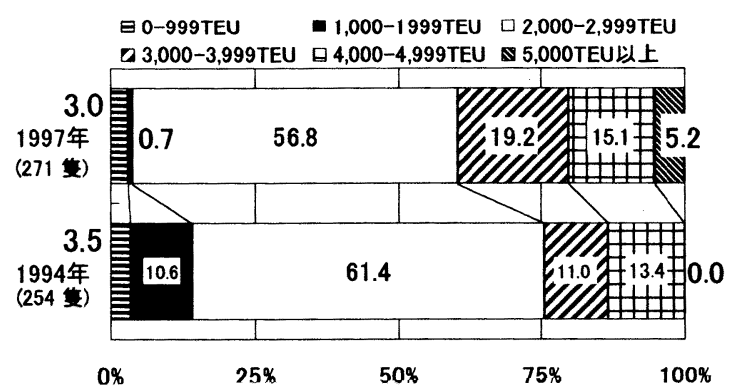

(各年参考文献6)より作成）

図-1＼cjkstart東アジア-北米西岸のコンテナ船の船型構成

\section{（5)船社の寄港地選択の要因}

船社からのヒアリングに基づき基幹航路における寄 港地の選定要因を分析した事例を図一2に示す。それに よれば, 寄港地の選定要因は, 地理的位置, 貨物量の 確保, 荷役機械使用料(ターミナル費用)の低廉なこと 等があげられる.また，寄港の実態から，ほとんどの 船社で船社の所属国および拠点とする港湾への寄港を 重視する傾向がみられ(貨物集貨の容易さが示す結果と も考えられる), さらに，運航航路から地理的に拠点と なる港湾にはほとんどのルートの船舶が寄港している ことが伺える。
つまり，船社は投入隻数の条件のなかで，寄港に見合 つた貨物が集荷でき，船舶が効率的に運航できるように 寄港地を選定しているといえる。

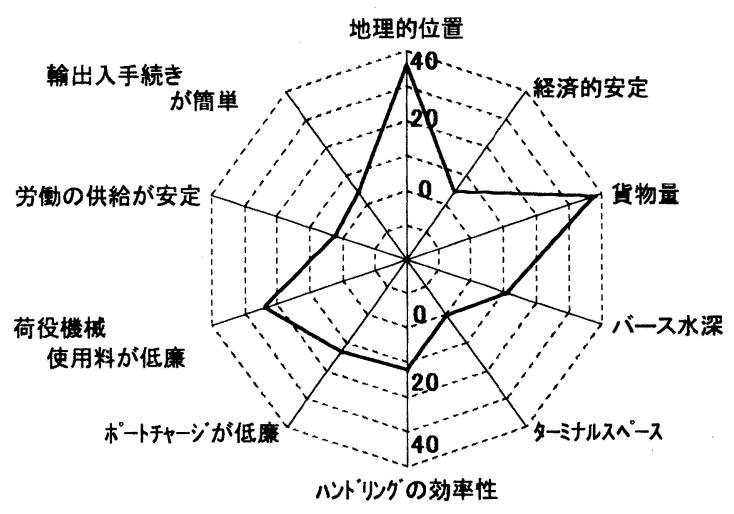

図-2＼cjkstart幹線航路における船社の寄港要因 ${ }^{8 !}$

\section{3. 船社の寄港挙動モテルの構築}

本分析ではフィーダー輸送による集荷と本船の寄港に 着目してモデルを検討した.

ある港湾で取り扱われるコンテナ貨物量のうち当該港 湾で本船に積み替えられる貨物量は，(1)その港の立地す る当該国・地域で生産・消費される貨物量(以下「ロー カルターミナル需要」と呼ぶ)のうち当該港湾で本船積 みされるダイレクト貨物と, (2)当該港湾周辺の国・地域 で生産・消費され，当該港湾にフィーダー輸送され当該 港湾で本船に積み替えられるトランシップ貨物の合計 (以下, 両者の合計を「拡大ターミナル需要」と呼ぶ)と なる.

図-3に, ダイレクト貨物, フィーダー貨物, トランシ ップ貨物の区分を示す.この図-3において，A港の拡大 ターミナル需要は， A港から本船に積み込まれる「(1)の ダイレクト貨物」と，「(3)のB港からのトランシップ貨 物（=(3'）」の合計となる。

一般に, 生産地では, 自国の港で本船に載せるか, 他

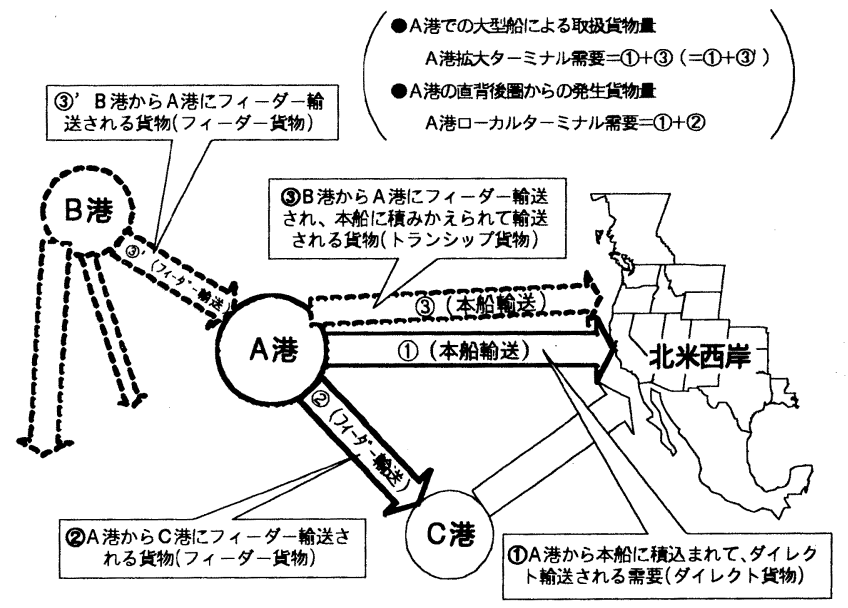

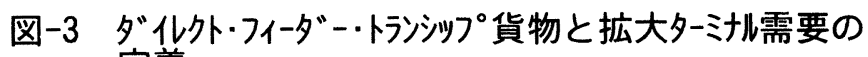
定義 
港にフィーダーするか, の2つの選択の余地がある.

一般にフィーダー輸送は，小型・中型船等で行われ， フィーダー先の港湾で本船への積替えが行われるため, 輸送日数が長い，輸送費用が高い，貨物の破損の可能 性も高い等のデメリットがあるが，港によっては本船 サービスの水準が低く，フィーダー船を選択しなけれ ばならない状況も多い。ただしフィーダー先の港湾と しては, 本船寄港数が多い等の条件を満足しても, 目 的地から大きくはずれ迂回を余儀なくされる港湾や， フィーダー距離が総輸送距離に比して大きくなる港湾 が選択される可能性は少ない。

また，本船の寄港に関して言えば，前出のとおり本 船の寄港は拡大ターミナル需要の大きさや港のサービ ス水準（荷役機械使用料，岸壁などの港湾施設等）に 大きく左右されることが知られている.

このような状況を踏まえ，本分析では，モデルの全 体構成を以下のとおり考えることとした。

\section{（1）モデルの全体構成}

今回の検討モデルは, 図-4に示すとおり, 各国・地 域の本船寄港隻数, 港湾料金, コンテナ船の運航コス トなどをもとに, 各国・地域のローカルターミナル需 要が自国・地域の港湾で本船利用となるか, 他の国・ 地域の港湾で本船利用となるかという選択確率を計算 し,フィーダー輸送も含めた需要である拡大ターミナ ル需要を計算するフィーダーサブモデルと, 得られた 拡大夕ーミナル需要と各国・地域での港湾サービス水 準 (バース延長等) やコンテナ船の船型構成などをも とに本船寄港隻数を予測する本船サブモデルからなる.

モデルは，フィーダーサブモデルに入力する各国・ 地域の本船寄港隻数と, 本船サブモデルから計算され る各国・地域の本船寄港隻数が収束するまで計算を繰 り返すフィードバックループを有し, 港湾料金・バー スの整備状況といった港のサービス水準や他の国・地 域からのフィーダー貨物も含めた拡大ターミナル需要 により, 貨物の流動状況, 船社の寄港行動がどう変化 するかを検討できるという特徵を有するモデルとなっ ている。

具体的には, フィーダーサブモデルにおいては, 各 国・地域 $\mathrm{i}$ の代表港 $\mathrm{i}$ を定め, 自国・地域からの発生 貨物（ローカルターミナル需要）が当該国・地域の代 表港 i から北米行きの本船に積み込まれるか, あるい は他の国・地域に小型船等でフィーダー輸送され，そ のフィーダー先において本船に積み込まれるかを考え， 候補となる各ルートの選択確率を計算する.

今回の分析では，この選択確率の計算にあたり，各 国・地域の本船寄港隻数Y1iを用いて寄港頻度をあらわ すダミ一変数の導入を行うこととしており，Y1iをもと に 1 週間に 1 便の本船寄港の場合にはウィークリーダ ミー, 毎日の本船寄港の場合にはディリーダミー，そ
して1日に多頻度（3 便）の本船寄港の場合には多頻 度ダミーとしてダミー変数を導入している．これらの 寄港頻度に関する説明変数やコンテナ船の入港・コン テナ貨物の荷役に関わる港湾料金, コンテナ船の運航 コスト等をもとに利用港湾別の選択確率を求め, 各国 ・地域 のフィーダー輸送分も含めた需要である拡大 ターミナル需要 Xiを求める.

また本船サブモデルにおいては，この拡大ターミナ ル需要 Xi ならびに, コンテナバースの整備量などを もとに, 各国・地域 $i$ の代表港 $\mathrm{i}$ における本船寄港隻 数Y2iを計算する.

こうして計算されるY2iとフィーダーサブモデルに入 力された本船寄港隻数Y1iを比較して, 各国・地域 $\mathrm{i} に$ ついて, Y1iとY2iが誤差 $1 \%$ 以内ならば計算を終了, 誤差が $1 \%$ 以上の際には, Y2iの值をY1iに代入して, 新たなY1iの值を設定したうえで再度フィーダーサブモ デルにフィードバックすることとなる.

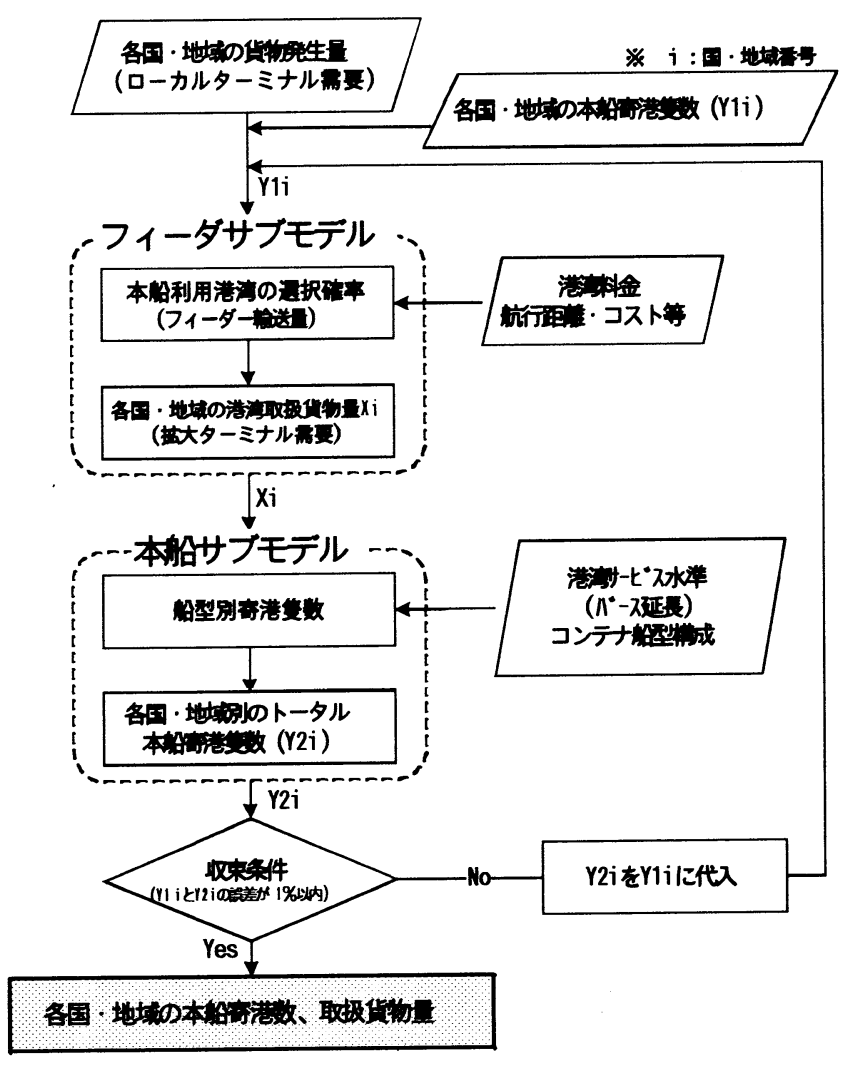

図-4 船社の寄港挙動モデルの全体フロー

\section{(2) 分析データ}

モデルの検討にあたっては, アジアの主要国・地域 と北米西岸とのコンテナ航路（東航）を対象に分析を 行った.

コンテナ貨物の流動状況については，表-3に示した デー夕を, また本船寄港隻数も同データからの実績值 を用いた. 更に 97 年現在の港湾整備量については各港 の資料から 97 年 1 月現在のコンテナバースの整備延長 
表-4 東アジアの主要国・地域間並びに北米西岸との運航距離

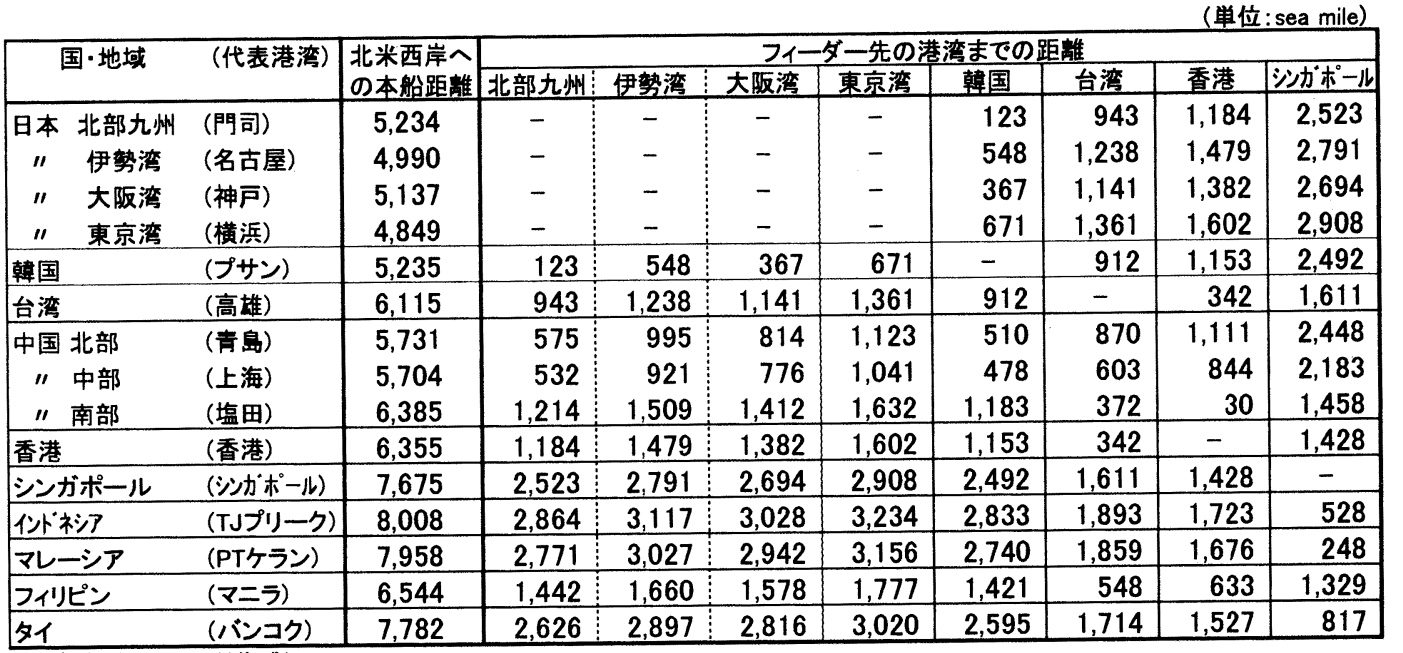

(参考文献12)13)より作成)

を整理して用いた。そのほかモデルの検討にあたり必 要となった運航コストについては運輸省で検討した輸 送コストモデル"，港湾料金については運輸省でのモデ ルケースでの料金計算結果 ${ }^{(0)}$ 準用した。

なお，モデルの適合性をみるために，97年データを 用いて検討したモデルを94年データに適用してモデル の再現性のチェックを行うにあたっては，上記のコン テナ貨物流動状況・本船寄港隻数については94年1月〜 3月の実績データ"1)を，また港湾料金やコンテナバース 延長については，94年1月現在のデータを用いた。

以下に主要なデータの概要を示す.

(1)分析対象国・地域と運航距離

今回のモデル検討にあたつては，表-3に示したアジ アの主要国・地域を分析の対象とした。ただし日本に ついては東京湾, 伊勢湾, 大阪湾, 北部九州の 4 地域 に，また中国については，北部（東北・華北），中部 （華中），南部（華南）の3 地域に分割して分析を進 めた。なお，分析対象国・地域の代表港湾間と北米西 岸との運航距離を表-4に示す.

\section{(2)バース延長}

港湾サービス水準として，大型コンテナ船寄港に対 応可能な水深 $(-12 m$ 以上)を備えた岸壁の総延長，すな わち2,000〜4,000TEUクラスのコンテナ船対応として水 深-12〜-14mのバースを，また近年増加している 4,000 TEUを超えるコンテナ船対応として，-14m以深のバース を考えた。具体的な施設整備量は表-5のとおりである.

(3)輸送コスト

運輸省で検討した参考文献》によるコンテナ船の運航 コスト(下記の式(1)参照)を用いた。

式中のパラメーター $\alpha$ は，固定費(千円/FEU)であり， 船の償却費用，税金，人件費などから構成される船費 のうち航行距離にかかわらず必要となるコストと停泊 中の燃料等の合計を, またパラメーター $\beta$ は距離に比 例する船費ならびに燃料費等の費用の単価(千円/sea mile·FEU)を表している. 表-5＼cjkstart東アジアの主要国・地域におけるバース延長

\begin{tabular}{|c|c|c|c|c|c|}
\hline & & & & & （単位: $\mathbf{m}$ ) \\
\hline 国·玨 & & 1994年 $\sigma$ & 整備桨況 & 1997年の & 整供桨況 \\
\hline & & 水梁-12 14m & 水深 $-14 m$ 以深 & 水梁 $-12 \sim 14 \mathrm{~m}$ & 水深-14m以泬 \\
\hline 日本 & 東京湾 & 5,780 & 1,300 & 6,020 & 2,350 \\
\hline & 伊繁湾 & 1,350 & 350 & 1,650 & 350 \\
\hline & 大阪湾 & 8,850 & 1,050 & 9,690 & 2,450 \\
\hline & 北部九州 & 720 & 0 & 1,020 & 0 \\
\hline 韓国 & & 1,262 & 900 & 1,262 & 1,200 \\
\hline 台湾 & & 3,756 & 3,200 & 4,396 & 3,605 \\
\hline 中国 & 北部 & 647 & 0 & 647 & 0 \\
\hline & 中部 & 0 & 0 & 784 & 0 \\
\hline & 南部 & 0 & 0 & 0 & 700 \\
\hline 香港 & & 3,587 & 1,100 & 3,587 & 2,380 \\
\hline シンカ & & 2,143 & 1,974 & 2,143 & 1,974 \\
\hline インド & & 0 & 0 & 0 & 0 \\
\hline RL- & & 1,280 & 0 & 1,280 & 0 \\
\hline フィリ & & 900 & 0 & 900 & 0 \\
\hline צ1 & & 0 & 900 & 0 & 900 \\
\hline
\end{tabular}

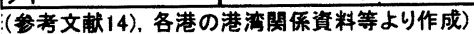

なお，東アジア域内のフィーダー輸送については， 就航船舶の実績などを考慮し今回の検討では300TEU積 みの船舶を, また北米西岸向けの船舶については，2， 000TEUクラス，4,000TEUクラスの2タイプの船を想定し， 所要の運航コストを算出した。

\begin{tabular}{|c|c|c|c|}
\hline \multicolumn{4}{|c|}{ 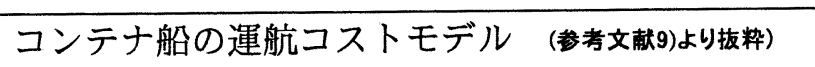 } \\
\hline \multicolumn{3}{|c|}{ 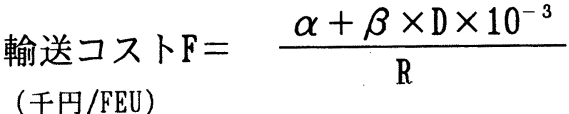 } & 式(1) \\
\hline \multicolumn{4}{|c|}{ 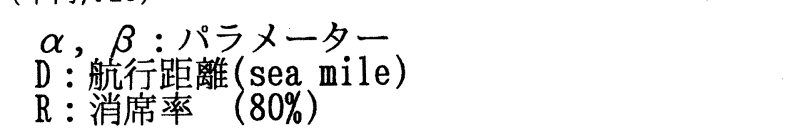 } \\
\hline \multicolumn{4}{|c|}{ (パラメーターの值 $)$} \\
\hline & 300TEU船 & 2,000TEU船 & 4,000TEU船 \\
\hline$\alpha$ & 13.40 & 4.07 & 2.56 \\
\hline$\beta$ & 37.40 & 10.10 & 5.96 \\
\hline
\end{tabular}

(4)港湾料金

港湾料金については，運輸省が試算したモデルケー スでの試算值を，為替レートで修正した表-6の值を用 いた. 
表-6＼cjkstart東アジアの主要国・港湾の港湾料金

\begin{tabular}{|l|r|r|}
\multicolumn{1}{|c|}{ (US \$/FEU) } \\
\hline 国 & 1997 年 & \multicolumn{1}{c|}{1994 年 } \\
\hline 日本 & 316 & 374 \\
\hline 香港 & 347 & 348 \\
\hline シンガポール & 177 & 172 \\
\hline 韓国 & 140 & 165 \\
\hline 台湾 & 158 & 172 \\
\hline
\end{tabular}

(参考文献 10)より作成)

(5)大型船比率

東アジア-北米西岸に就航しているコンテナ船の船型 構成については，実際のコンテナ船の就航状況から 94 年ならびに97年について，それぞれ表-7のように設定 した.

表-7 東アジア-北米西岸のコンテナ船の船型構成

\begin{tabular}{|c|c|c|}
\hline & $2,000 \sim 4,000 T E U$ & $4,000 T E U 以 上$ \\
\hline 1994年 & 0.90 & 0.10 \\
\hline 1997年 & 0.81 & 0.19 \\
\hline
\end{tabular}

\section{（3）フィーダーサブモテル}

船社は需要発生地からの貨物輸送に際して, (1)需要 発生地の港湾からのダイレクト航路を利用するか, (2) 周辺他国の港湾へフィーダー輸送しフィーダー先の港 湾で本船に積み込むか, またそのフィーダー先の港湾 としてはどこを選択するのかについて，様々な要因を 比較検討し，いずれかのルートを選択しているものと 考えられる.

今回の分析では，一般的なコンテナ貨物の輸送にお いては, ダイレクト輸送, 周辺の国・地域へのフィー ダー輸送利用といったすべての輸送ルートの候補に関 して，時間や費用などが同時比較されたうえでルート 選択が決定されると考え，モデル構造を段階選択では なく通常の集計ロジット型に設定することとした。

具体的には, フィーダーサブモデルは, 図-5に示す ように $\mathrm{i}$ 国・地域の代表港 $\mathrm{i}$ 港を定め, 自国・地域 $\mathrm{i}$ からの発生貨物が, ダイレクト貨物として輸送される か, $\mathrm{k}$ 港あるいは $\mathrm{j}$ 港へのフィーダー輸送貨物として 輸送されるかを考え, 候補となる各ルート r の選択確 率Pirを求める下記の集計ロジット型モデルを考えた.

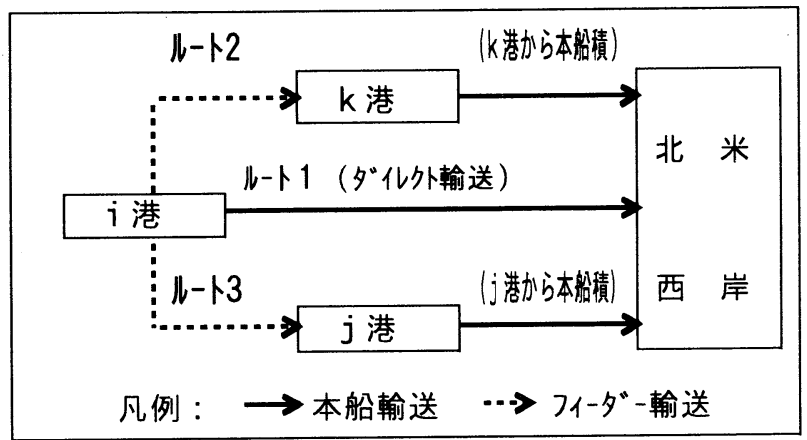

図-5 フ1ダーサブモデル構築時の選択ルート例

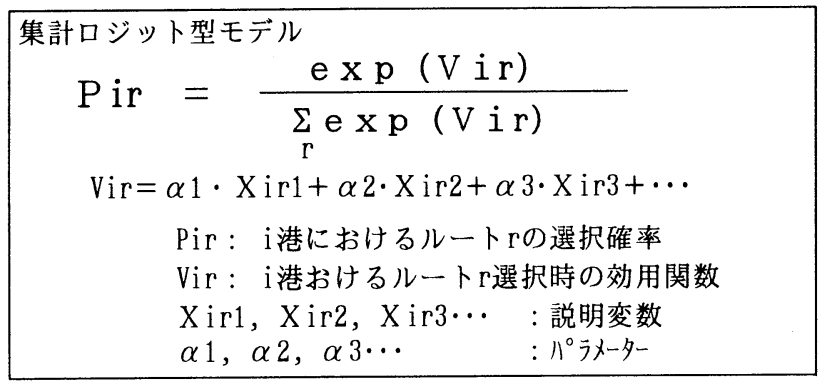

説明変数としては，各港湾での港湾コスト，本船な らびにフィーダー輸送の輸送コスト, 本船への積み込 み港湾の本船寄港頻度（ウイークリーサービス多ミ゙ーテディリーサービ 多゙ミ一，1日3寄港程度のサ-ビスレベルを表す多頻度サービ 夘゙ミ一），中国と香港や台湾との特殊な交易事情を表 すダミー変数等を検討した.

また,フィーダー輸送貨物を本船に積み替えるトラ ンシップ港としては, 現状のトランシップ貨物量や港 湾の整備状況, 地理的条件等を考慮して, 日本の 4 地 域, 台湾, シンガポール, 香港, 韓国の 8 地域とした。

なお, 精密機械輸送などの一部のコンテナ輸送にお いては, 荷傷み防止等の観点から極力積み替え回数を 減らしたい意向が強いと言われていることから, ダイ レクト輸送かフィーダー輸送か, 更にはフィーダー輸 送であるとするとどの港湾をフィーダー先として選択 するかといった段階的選択を考えるモデル構造 (Nest ed Logitモデル）の検討も今後の課題と考えている.

\section{（4）本船サブモテル}

船社が本船を寄港させるかどうかは, 集荷できる貨 物量並びに入港に必要な施設が十分整備されているか が大きな要因であることから，以下の構造式を考えた。

なお, 需要量としては, ダイレクト貨物に加え, 他 国・地域からフィーダー輸送され当該港湾で本船に積 み替えられる貨物（トランシップ貨物）をあわせた需 要（拡大ターミナル需要）を考えた。

なお，本船サブモデルの構築にあたつては，従来モ デルでは考慮されていなかった水深区分によるバース 延長をモデルの説明変数に導入した他, 船型区分 $(20$ 00〜4000TEU，4000TEU以上）も考虑した。

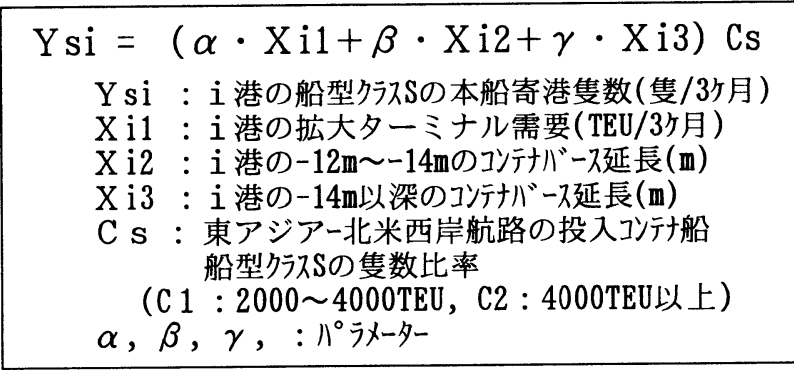

\section{( 5 ） サブモテルのパラメーター推計} (1)フィーダーサブモテル

フィーダーサブモデルのパラメーター推計結果を表 
-8に示す. $t$ 值, 相関係数から判断して, 概ね良好な 説明力を有するモデルが構築できた.

特に, 説明変数としては「輸送コスト」と1日1便の サービスを表す「ディリーサービス」が大きな説明力 を有していることがわかる。ここで，表-8のモデル1に ついて，その現況再現性を検証した。

その結果を図-6に示す.図-6より，フィーダーサブ モデル1については，韓国において拡大ターミナル需要 が若干過大推計, 東京湾で若干過小推計とはなるもの の，概ね良好な結果が得られた。

表-8 フイダーサブモデルのパラメータ-推計結果

\begin{tabular}{|c|c|c|c|c|}
\hline & \multicolumn{2}{|c|}{ モデル 1} & \multicolumn{2}{|c|}{ モデルル2 } \\
\hline 重相関R & \multicolumn{2}{|c|}{0.80} & \multicolumn{2}{|c|}{0.79} \\
\hline 重決定R2 & \multicolumn{2}{|c|}{0.64} & \multicolumn{2}{|c|}{0.63} \\
\hline サンプル数 & \multicolumn{2}{|c|}{100} & \multicolumn{2}{|l|}{100} \\
\hline 説明変数 & 係数 & t値 & 係数 & $\mathrm{t}$ 値 \\
\hline 港湾了不 & $-1.39 \mathrm{E}-2$ & -4.3 & $-1.24 \mathrm{E}-2$ & -3.9 \\
\hline 輸送コス卜 & $-4.96 \mathrm{E}-2$ & -5.8 & $-5.13 E-2$ & -6.0 \\
\hline ウィークリーサービス & 7.76 & 2.8 & 7.35 & 2.6 \\
\hline ディリーサービス & 7.64 & 7.4 & 7.77 & 7.4 \\
\hline 多䫄度サービス & $8.20 \mathrm{E}-1$ & 1.5 & 1.05 & 2.0 \\
\hline 中国台湾㚈 :- & -1.65 & -1.8 & -2.31 & -2.7 \\
\hline 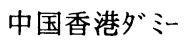 & 4.36 & 1.9 & - & - \\
\hline
\end{tabular}

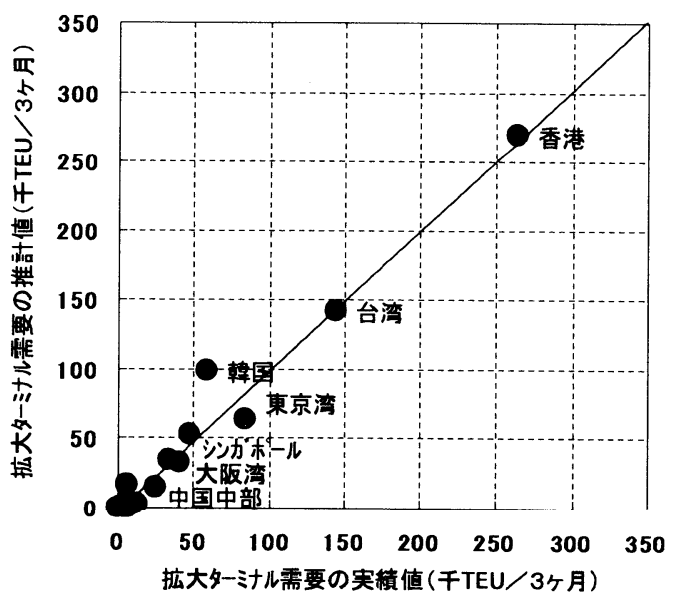

図-6フィーダーサブモデルの現況再現性

\section{(2)本船サブモテル}

本船サブモデルのパラメーター推計結果を表-9に示 す. $\mathrm{t}$ 值, 相関係数から判断して, 概小良好な説明力 を有するモデルが構築できた。

ここで，表-9の本船サブモデルの現況再現性を検討 したそその検討結果を図一7に示す。これより，各港湾 について，2,000〜4,000TEUクラスの寄港隻数モデル において，伊勢湾ならびに韓国の本船隻数が実績值に 比べて過小推計となったものの，概ね良好な結果が得 られた。 表-9＼cjkstart本船サブモデルのパラメータ-推計結果

\begin{tabular}{|c|c|c|c|c|}
\hline & \multicolumn{2}{|c|}{$\begin{array}{r}2000 \sim 4000 \text { TEU } \\
\text { 隻数比虽 } 1=0.8)\end{array}$} & \multicolumn{2}{|c|}{$\begin{array}{l}\text { 4000TEU以上 } \\
\text { 隻数比事 } 11=0.2)\end{array}$} \\
\hline 重相関R & \multicolumn{2}{|c|}{0.93} & \multicolumn{2}{|c|}{0.94} \\
\hline 重決定 R ${ }^{2}$ & \multicolumn{2}{|c|}{0.87} & \multicolumn{2}{|c|}{0.89} \\
\hline サンプル数 & \multicolumn{2}{|c|}{15} & \multicolumn{2}{|c|}{15} \\
\hline 説明変数 & 係 & $\mathrm{t}$ 值 & 数 & $t$ 值 \\
\hline 拡大夕ーミ十川需要 & $7.38 \mathrm{E}-4$ & 3.2 & $1.53 \mathrm{E}-3$ & 5.9 \\
\hline$-12 \sim-14$ バ - ス長 & $1.22 \mathrm{E}-2$ & 2.0 & - & - \\
\hline -14m以深バ-ス長 & $4.27 \mathrm{E}-2$ & 2.3 & $2.44 \mathrm{E}-2$ & 1.7 \\
\hline
\end{tabular}
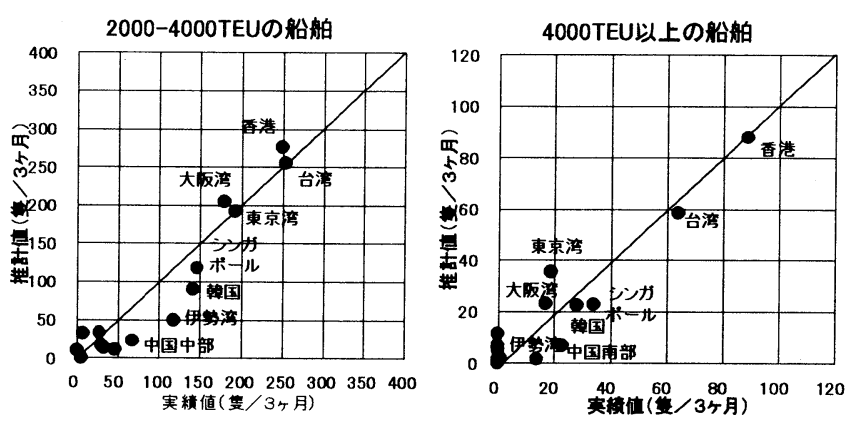

困-7＼cjkstart本船サブモデルの現況再現性

\section{（6）モテル全体系での現況再現性の検討}

各国・地域から発生するローカル貨物を初期条件と し，図-4のモデルの全体フローに従い，表-8のフィー ダーサブモデル1と表-9の本船サブモデルのパラメータ 一を用いて絽り返し計算を行い，本船寄港隻数と各国 ・地域の拡大ターミナル需要を算出した。その結果を 表-10, 図-8に示す.

中国，伊勢湾の隻数ならびに拡大ターミナル需要が 過小推計, 韓国の拡大夕ーミナル需要が過大推計等と なっており，一部に予測値と実績值の乘離が見られる が, 実績值と予測值の相関係数（自由度調整済）は本 船寄港隻数では 0.87 , 拡大夕ーミナル需要では0.92あり, 比較的良好な現況再現性が確認された。

なお，中国，伊勢湾に関して予測值と実績值が乘離 しているのは，実績ではその寄港隻数から判断してデ イリーサービスであるものの, 予測においては, 絽り 返し計算過程において本船寄港隻数がディリーサービ スか否かの判断となる 90 便（３ヶ月間）を下回って しまうため, フィーダーサブモデルにおいて大きな説 明力を有するディリーダミーの影響を大きく受け，拡 大ターミナル需要も過小推計されるためと推察される.

また，この中国貨物の自国・地域からの本船利用貨 物の過小推計に伴い, 韓国へのフィーダー輸送が過大 推計され, 韓国の拡大夕ーミナル需要も実績值よりも 大きく推計されることとなったと推察される. 
表-10 モ干ル全体系での1997年值の現況再現性検討結果

\begin{tabular}{|c|c|c|c|c|}
\hline & \multicolumn{2}{|c|}{ 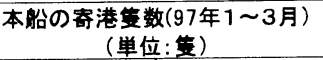 } & \multicolumn{2}{|c|}{$\begin{array}{c}\text { 各国の港滦の桩大ターミナル需要 } \\
\text { (単位: TEU) }\end{array}$} \\
\hline & 実縝值 & 推計值 & 実縝值 & 推計値 \\
\hline 中国 & 135 & 41 & 43,327 & 51 \\
\hline 台湾 & 390 & 319 & 144,242 & 150,877 \\
\hline 香港 & 416 & 376 & 264,253 & 278,121 \\
\hline 韓国 & 213 & 180 & 58,829 & 135,552 \\
\hline シンガポール & 170 & 157 & 47,349 & 66,142 \\
\hline 北部九州 & 49 & 10 & 5,114 & 0 \\
\hline 伊勢湾 & 185 & 31 & 33,612 & 761 \\
\hline 大阪滦 & 265 & 221 & 40,290 & 32,793 \\
\hline 東京湾 & 320 & 209 & 84.553 & 64,568 \\
\hline 日本合計 & 819 & 471 & 163,569 & 98,122 \\
\hline インドネシア & 3 & 0 & 142 & 0 \\
\hline マレーシア & 38 & 13 & 5,588 & 257 \\
\hline フィリピン & 0 & 9 & 0 & 0 \\
\hline 夕1 & 46 & 36 & 2,906 & 1,083 \\
\hline & 2,230 & 1,602 & 730,205 & 730,205 \\
\hline
\end{tabular}

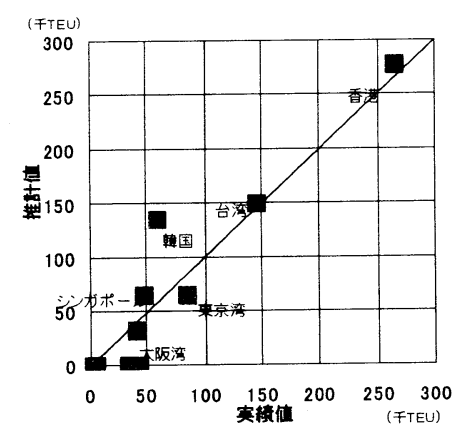

（実縝値と予測値の相関） 相関係数(自由度調整済) 本船寄港隻数 \begin{tabular}{|l|l|}
\hline 拡大ターミナル需要 & 0.92 \\
\hline
\end{tabular}

図-8モデル全体系での拡大夕-ミ驯需要(97年)の現況再現性

\section{（7）モテルの適用性の検討}

ここでは，モデルの移転性についての検討を行った。 具体的には，（6）と同様に表-8のフィーダーサブモ デル1と表-9の本船サブモデルのパラメーターを用いて， 1994年1月〜3月の実績デー夕の再現性を検討した.

表-11に検討結果を示す. 表より，本船隻数が日本諸 港, 香港で過小推計, 拡大ターミナル需要に関しては, 韓国で過大推計, 伊勢湾, 大阪湾等で若干過小推計等 となっており，一部に実績值と予測值の乘離がみられ るが, 実績值と予測值の相関係数は本船寄港隻数で 0 . 88, 拡大夕ーミナル需要で0.91あり, 97年データで構 築したモデルのパラメーターを94年実績データに適用 しても，（6）での97年值の現況再現と同様に，比較 的良好な現況再現性を有していることが確認できた。 よって, 以下ではこのモデルを用いて, 将来予測を行 うこととした。

表-11 王川全体系での1994年值の現況再現性検討結果

\begin{tabular}{|c|c|c|c|c|}
\hline & \multicolumn{2}{|c|}{ 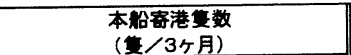 } & \multicolumn{2}{|c|}{$\begin{array}{l}\text { 桩大ターミナル需要 } \\
\text { (単位:TEU/3ケ月） }\end{array}$} \\
\hline & 94年1 3月英續 & 推計值 & 94年1 3月实繹 & 推計值 \\
\hline 中国 & 1 & 0 & 2 & 0 \\
\hline 台湾 & 305 & 307 & 173,977 & 165,824 \\
\hline 香港 & 282 & 216 & 184,382 & 161,549 \\
\hline 㬍国 & 147 & 139 & 41,745 & 109,275 \\
\hline シンガポール & 112 & 157 & 35,795 & 65,104 \\
\hline 北部九州 & 40 & 8 & 3,337 & 0 \\
\hline 伊勢湙 & 143 & 30 & 28,245 & 981 \\
\hline 大阪湾 & 233 & 170 & 54,910 & 35,859 \\
\hline 東京湾 & 246 & 165 & 73,949 & 58,001 \\
\hline 日本合計 & 662 & 373 & 160,441 & 94,841 \\
\hline インドネシア & 8 & 0 & 143 & 0 \\
\hline マレーシア & 20 & 14 & 1,482 & 254 \\
\hline フィリピン & 8 & 10 & .28 & 0 \\
\hline 夕1 & 1 & 38 & 1 & 1,148 \\
\hline 計 & 1,546 & 1,254 & 597,996 & 597,996 \\
\hline
\end{tabular}

\section{2010年におけるコンテナ航路体系の分析}

以上の検討により構築できたフィーダーサブモデル 1 と本船サブモデルを用いて，2010年における東アジ アー北米西岸航路体系の分析を行った。

\section{（1）2010年のローカル需要}

2010年の東アジアの主要国から北米西岸へのローカ ル需要については, 東アジア主要国のGDP合計と北米向 けコンテナ貨物量との相関が高いことから，87〜96年 のデータを用い，回帰式を式(2)のとおり算出した.

貨物量 $=9.55 \mathrm{E}-2 *($ アジア全体GDP) -900 式(2)

$[千 \mathrm{TEU} /$ 年 $] \quad[$ 億 $\$] \quad($ 相関係数 $\mathrm{R}=0.96)$

次に経済企画庁発表の東アジア各国の2010年までの 経済成長率をもとにアジア主要国のGDP将来值を求め, 2010年における東アジア $\rightarrow$ 北米のコンテナ輸送量を算 出, 更に各国の現行の貨物取扱シェアと各国の将来GD P成長率をもとに各国に配分するという簡便法をとつた。 その結果を表-12に示す。

表-12 2010年四半期の東アジアー北米西岸のロ-玑需要

\begin{tabular}{|c|c|c|c|}
\hline & $\begin{array}{l}\text { 2010年1～3月 } \\
\text { 口-加需要 } \\
\text { [千TEU] }\end{array}$ & $\begin{array}{l}\text { (参考1) } \\
\text { 1997年1～3 } \\
\text { 月ロ-力川需要 } \\
\text { 実縝[壬TEU] }\end{array}$ & $\begin{array}{l}\text { (参考2) } \\
\text { 1996年〜 } \\
\text { 2000年実質 } \\
\text { 経済成長率 }\end{array}$ \\
\hline 日本 & 177.8 & 149.7 & $2.2 \%$ \\
\hline 韓国 & 93.5 & 49.5 & $3.9 \%$ \\
\hline 台湾 & 206.3 & 106.8 & $4.3 \%$ \\
\hline 香港 & 190.6 & 103.0 & $4.0 \%$ \\
\hline 中国 & 618.2 & 239.6 & $7.2 \%$ \\
\hline シンガポール & 27.8 & 12.4 & $4.8 \%$ \\
\hline 工件次 & 32.2 & 22.0 & $5.1 \%$ \\
\hline アレ-シア & 95.6 & 27.7 & $8.1 \%$ \\
\hline インド䄈 & 56.8 & 29.8 & $5.4 \%$ \\
\hline 夕1 & 91.6 & 38.7 & $6.2 \%$ \\
\hline 合計 & 1590.5 & 779.2 & - \\
\hline
\end{tabular}

注)経済成長率は参考文献15)16)による

\section{( 2 ）パース延長}

2010年における東アジアの各国・地域におけるコン テナバース延長については, 各港の将来計画資料等を もとに表-13のとおり設定した。

表-132010年における各国・地域のコンテナバース延長

\begin{tabular}{|c|c|c|c|c|}
\hline & $\begin{array}{c}\text { 将来計画 } \\
\text { 水深-12 } \\
\sim-14 \mathrm{~m}\end{array}$ & $\begin{array}{l}010 \text { 年) } \\
-14 \mathrm{~mL} \\
\text { 深 }\end{array}$ & $\begin{array}{c}\text { (参考) } \\
\text { 水深-12 } \\
\sim-14 \mathrm{~m} \\
\end{array}$ & $\begin{array}{l}97 \text { 年 } \\
-14 \mathrm{~m} \text { 以 } \\
\text { 深 }\end{array}$ \\
\hline $\begin{array}{l}\text { 東京湾 } \\
\text { 势湾 } \\
\text { 大阪湾 } \\
\text { 北部九州 }\end{array}$ & $\begin{array}{l}3220 \mathrm{~m} \\
1650 \mathrm{~m} \\
6000 \mathrm{~m} \\
2550 \mathrm{~m} \\
\end{array}$ & $\begin{array}{l}8650 \mathrm{~m} \\
3350 \mathrm{~m} \\
9800 \mathrm{~m} \\
1690 \mathrm{~m} \\
\end{array}$ & $\begin{array}{l}6020 \mathrm{~m} \\
1650 \mathrm{~m} \\
9690 \mathrm{~m} \\
1020 \mathrm{~m} \\
\end{array}$ & $\begin{array}{r}2350 \mathrm{~m} \\
350 \mathrm{~m} \\
2450 \mathrm{~m} \\
0 \mathrm{~m} \\
\end{array}$ \\
\hline 韓国 & $1262 m$ & $8270 \mathrm{~m}$ & $1262 m$ & $1200 \mathrm{~m}$ \\
\hline 台湾 & $5656 \mathrm{~m}$ & $6545 \mathrm{~m}$ & $4396 \mathrm{~m}$ & $3605 \mathrm{~m}$ \\
\hline 香港 & $3587 \mathrm{~m}$ & $7500 \mathrm{~m}$ & $3587 \mathrm{~m}$ & $2380 \mathrm{~m}$ \\
\hline 中国 & $5276 \mathrm{~m}$ & $8825 \mathrm{~m}$ & $1431 \mathrm{~m}$ & $700 \mathrm{~m}$ \\
\hline シ่がポール & $2143 \mathrm{~m}$ & $11399 \mathrm{~m}$ & $2143 \mathrm{~m}$ & $1974 \mathrm{~m}$ \\
\hline フ化゚ン & $900 \mathrm{~m}$ & $1300 \mathrm{~m}$ & $900 \mathrm{~m}$ & $0 \mathrm{~m}$ \\
\hline マレ-シア & $1079 \mathrm{~m}$ & $1523 \mathrm{~m}$ & $1280 \mathrm{~m}$ & $0 m$ \\
\hline 仪゙祊? & $490 \mathrm{~m}$ & $900 \mathrm{~m}$ & $0 \mathrm{~m}$ & $0 \mathrm{~m}$ \\
\hline 夕1 & $0 \mathrm{~m}$ & $1200 \mathrm{~m}$ & $0 \mathrm{~m}$ & $900 \mathrm{~m}$ \\
\hline
\end{tabular}

（参考文献14），各港港湾計画資料等より作成） 


\section{( 3 ) ケーススタティ}

上記（1）（2）のローカルターミナル需要, バー ス延長等を初期条件として，2010年における各国・地 域の本船寄港隻数, 拡大ターミナル需要を計算した。

近年のコンテナ船の大型化の動向の影響を見るため に，また現状のままの大型船 2 割で推移したケースと の比較をするために，計算にあたっては，4000TEUを超 える大型コンテナ船の比率を現行の 2 割としたケース Aのほか, 大型船比率を 4 割, 6 割にあげるケース B , Cを設定した。 また，今後の我が国での大型バースの 整備如何によりどのような影響がでるかを見るために， 日本では新たに大水深バース (-14m以深) を整備しな いケース D，さらには今後のソフト面での対応がどの ように国際航路体系に影響するかをみるために，日本 の港湾料金 $(316$ \$/個) を釜山並 (140\$/個) まで下 げるケースEについてシミュレーションを行った。そ の結果を表-14, 図-9·10に示す．表-14及び図-9·10よ り以下のことがわかる.

1) ケース A，B，Cより，コンテナ船の大型化に伴 い, 大水深バースの比率が他国・地域に比べ低い台 湾や日本では取扱貨物量が減少することがわかる.

2 ) 大型船 4 割のケースBの条件を変え, バース整備 条件を日本では大水深バースを今後整備しないとし たケースDでは, 日本の貨物が $6 \%$ 減となり, 我が国 のローカル需要が他国・地域にフィーダー輸送され

ることがシミュレーションされた。

3 ) 更にケースBの条件のうち，日本における港湾料 金のみ釜山並まで下げるとしたケース Eにおいては， 日本全体で74\%の貨物増（港湾別には北部九州 $332 \%$ ， 大阪湾 $119 \%$ ，東京湾 $41 \%$ 増），逆に韓国貨物が $22 \%$ 減 となることがシミュレーションされた.

4 ) 寄港隻数についても, 大型船が 2 割, 4 割, 6 割 と増大するにつれ日本への寄港隻数が減少すること， また，日本に大水深バースを整備しないケースDで は，ケースBに比べ $47 \%$ の寄港隻数減になることがシ ミュレーションされた。

表-14 2010年のケーススタディ結果

\begin{tabular}{|c|c|c|c|c|c|c|}
\hline & & $r-\lambda A$ & $h-\pi B$ & $4-\pi C$ & T-XD & $4-X E$ \\
\hline & パース部 & 圾国どおり & 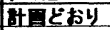 & 部どおり & 旦本大水敢勧 & カ十どおり \\
\hline & 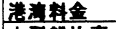 & 国状どお山 & 理犾どお山 & 国获どお山 & 珼获とお山 & 白本斜山亚 \\
\hline & 大翼批事 & 2. (渭状) & 4 & 6 . & 4. & 4: \\
\hline \multirow{10}{*}{ 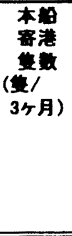 } & 東京淿 & $\begin{array}{r}446 \\
\end{array}$ & 418 & 392 & 241. & 454 \\
\hline & 大臤 & 485 & 434 & 391 & 228 & 487 \\
\hline & G & 188 & 179 & 170 & 94 & 196 \\
\hline & $\ldots$. & 101 & 90 & $\ldots 66$ & 31 & 124 \\
\hline & 旦本合部 & 1,220 & 1,121 & 1,019 & 594 & 1,134 \\
\hline & 国 & 556 & 561 & 571 & 569 & 503 \\
\hline & 台流 & 612 & 618 & 611 & 618 & 602 \\
\hline & 㴡港 & 691 & 729 & 765 & 731 & 674 \\
\hline & 中国 & 608 & 601 & 594 & 602 & 592 \\
\hline & ジカが & 618 & 608 & 611 & 608 & 603 \\
\hline \multirow{10}{*}{ 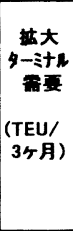 } & 辣京云 & 84.194 & 83.855 & 83,703 & 83,765 & 118,196 \\
\hline & 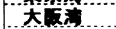 & 47,122 & 41,549 & 41.415 & 41.066 & 91174 \\
\hline & 㑛 92 & 45,729 & 45,476 & 45.371 & 45.431 & 62.146 \\
\hline & 南九为 & 10.676 & 10.122 & 25 & 19 & 43,700 \\
\hline & 自本合部 & 187,722 & 181,002 & 170,514 & 170,281 & 315,216 \\
\hline & 疅 & 246,653 & 245,383 & 250,081 & 253,371 & 191,008 \\
\hline & 台语 & 337,673 & 326,986 & 309,779 & 327,865 & 312,631 \\
\hline & 香港 & 407,148 & 415,455 & 420,403 & 417.071 & 362,411 \\
\hline & 中国 & 24 & 239,750 & 240,550 & 239,934 & 232,563 \\
\hline & 齐少が & 169,261 & 179,937 & 196,848 & 180,033 & 174,823 \\
\hline
\end{tabular}

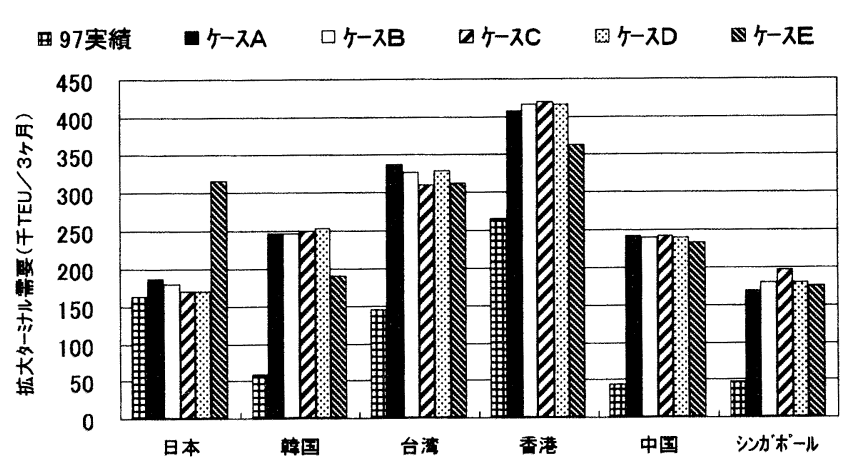

図-9２010年主要国拡大ターミナル需要推計結果

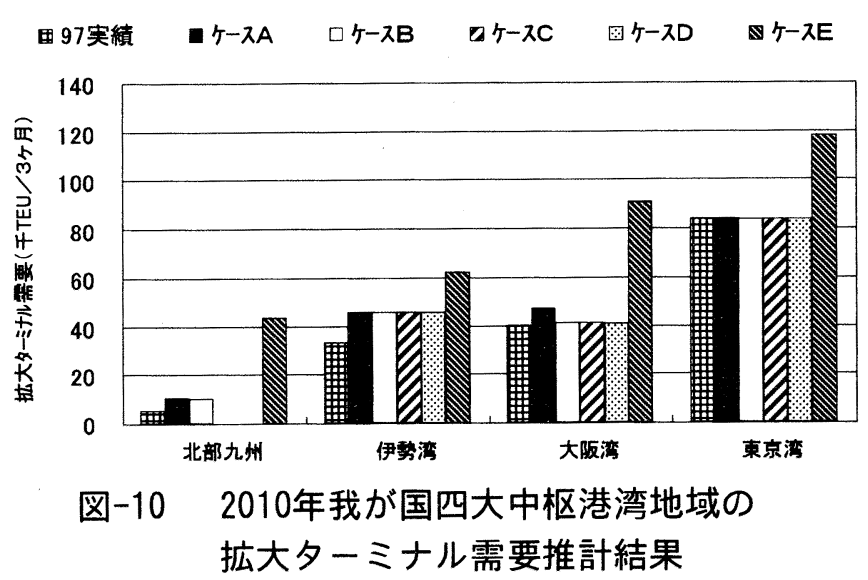

\section{5.まとめ}

今回の検討では, 船社の行動結果としての国際コン テナ船の寄港隻数やフィーダー輸送による貨物量等を, 港湾料金, 港湾施設の整備状況, 輸送工外, 運航頻度等 でマクロに捉え, その状況を説明するモデルが構築で き, 今後のコンテナ船の大型化や大水深バースの整備 如何によって, 我が国への大型船の寄港や取扱貨物量 が変化することが検証できた。

ただし，フィーダーサブモデルや本船サブモデルに ついては, 実績值と予測值の一部乘離もみられること からいっそうの精度向上・改良が望まれる他, 我が国 の将来需要の 4 大中枢港湾への配分問題, 空コンテナ の問題, 今後のコンテナ船の大型化等の船型予測問題, 港湾におけるソフト面のサービスや自社ターミナルと 寄港の関連など課題も残されている.

今後は，アジアー北米航路（西航）や欧州航路など 他の基幹航路についての検討も含め, 本モデルを更に 改良・発展させ, 今後の港湾政策を考える際の基礎資 料となる将来の本船寄港やコンテナ貨物流動の状況を より正確に予測できるよう, 引き続き分析を進めたい。 本研究の実施にあたり，(㒖)三菱総合研究所 森浩氏， 加藤二朗氏の協力をえた.ここに謝辞を表するもので ある。 


\section{参考文献}

1)木村東一 : 外貿港湾選択評価手法とその応用に関す る研究, 京都大学博士論文, 1985.11

2)郭子堅, 長尾義三, 榛沢芳雄 : 国際コンテナ輸送祅トワーク の再編に関する基礎的研究, 港湾経済研究 No.33. 1995.3, pp255-269

3)黑田勝彦，楊賛 : 国際川ブ・コソテナ・ターミナルの最適祅ワー 計画,地域応用科学研究会発表論文, 1994.12

4)家田 仁, 柴崎隆一, 内藤智樹 : アジア圏国際コン テナ貨物流動モデルとその配分原理に応じた特性比 較, 土木計画学研究・講演集20，1997.11

5)村田利治, 渡部富博, 石川浩章 : 幹線コンテナ定期航路 における船社の寄港挙動モデル：日本沿岸域学会論 文集, 1998.3

6)オーシャンコマース社:国際輸送ハンドブック

7)Journal of Commerce:Piers Port Import Export Reporting Services, 1997.1-1997.3
8)運輸省港湾局: コンテナ航路網の再編による港湾への 影響調査報告書, 1992.3

9)森浩ほか：土木学会土木計画学研究講演集No.17:外 貿コソテナ輸送コス卜モデルの開発，1995.1

10）（財）日本海事広報協会 : 平成 9 年日本海運の現況

11) Journal of Commerce:Piers Port Import Export Reporting Services,1994.1-1994.3

12）（社）日本海運集会所：Distance Tables for World Shipping

13)日本航海土会 : World-wide Distance Chart

14)The National Magazine Co. Ltd. :Containerization International Year Book 1995, 1998

15)経済企画庁:グローバリゼーション・ワーキンググル 一プ報告書， 1998.4

16)経済企画庁:グローバリゼーションと 21 世紀経済の課 題, 1997.5

\section{船社の寄港挙動モデルによる国際コンテナ航路体系の分析}

本研究は, 東アジアー北米西岸航路（東航）を対象に, コンテナターミナル整備と船社の行動に着目し, その寄港地選択を説明するモデル構築を行い，国際コンテナ航路体系の分析を行ったものである.

分析では, 国際コンテナ航路の寄港隻数, フィーダー輸送貨物等を港湾料金, 港湾施設, 輸送コス卜, 運 航頻度等で説明するモデルの構築ができた。

また, 構築したモデルにより, 2010 年における東アジア地域でのコンテナ貨物流動, 大型船の本船寄港 の状況等を様々なケースによりシミュレーションでき, 港湾料金や船舶の大型化, 大水深バースの整備等が 今後の港湾整備の重要なファクターであることが確認された。

A modeling of Carriers' Behavior of Container Ship Calling at Ports

- Routes between East Asia and West Coast of North America-

Tomihiro WATANABE, Masakazu YOSHIMI, Hironori ISHIBASHI

In this paper, container demand and ship routings from East Asia to the West coast of North America (east bound) are analyzed. Then port facilities and behavior of ship owners are studied to find the relationship between them and ship routing.

Model to explain the number of callings and feeder routings are constructed. The main explanatory factors are port fees, facility levels, and transport costs.

This model can also be used to show routing in East Asia in 2010. It is confirmed that reduction port fees and development of deep berths are key factors in establishing the Japanese container routing system. 